Marquette University

e-Publications@Marquette

$3-1-2013$

\title{
Environmental Performance of State-Owned and Privatized Eastern European Energy Utilities
}

Andrew G. Meyer

Marquette University, andrew.g.meyer@marquette.edu

Grzegorz Pac

Alfred University

NOTICE: this is the author's version of a work that was accepted for publication in Energy Economics. Changes resulting from the publishing process, such as peer review, editing, corrections, structural formatting, and other quality control mechanisms may not be reflected in this document. Changes may have been made to this work since it was submitted for publication. A definitive version was subsequently published in Energy Economics, Vol. 36, (March 2013): 205-214. DOI. (C) 2013 Elsevier. Used with permission.

Andrew Meyer was affiliated with Ohio Wesleyan University at the time of publication. 


\title{
Environmental Performance of State-Owned and Privatized Eastern European Energy Utilities
}

\section{Andrew Meyer ${ }^{\ddagger}$ and Grzegorz Pac ${ }^{\dagger}$}

\author{
August 9, 2012
}

\begin{abstract}
Privatization in Eastern Europe has helped transition the region's economies from planned to free market. However, the effects of privatization on the environment are relatively unknown and many firms remain under state ownership today. We compare the environmental performance of state-owned and privatized energy utility plants in Eastern Europe utilizing a novel panel data that includes reported sulfur dioxide emissions, energy input, and ownership status. We find that state-owned plants emit more sulfur dioxide than privately owned plants; this is environmentally significant as privatization is associated with a reduction in emissions of about 55 percent.

Keywords: privatization, state-owned enterprises, electricity industry, enivronmental quality

JEL classification paper: P31, Q48, Q53.

${ }^{\ddagger}$ Corresponding author: Assistant Professor of Economics, Ohio Wesleyan University, 61 South Sandusky Street, Delaware, OH 43015. email: agmeyer@owu.edu

†Assistant Professor of Economics, College of Business, Alfred University, 1 Saxon Dr., Alfred, New York 14802. email: pac@alfred.edu.
\end{abstract}




\section{Introduction}

There are various reasons why a country may or may not choose to retain public ownership of energy utilities. ${ }^{1}$ Using Poland as an example, the Polish Ministry of Economy listed three objectives for its energy industry in 2000: 1) energy security 2) improvement of competitiveness in energy sector and 3) protection of the environment (Jouret, 2006). Polish citizens that are used to state-owned energy utilities might view government control of energy as more secure than private control (Nestor and Mahboobi, 2000). Competitiveness would theoretically improve with privatization (Holder, 2000). However, it is not conceptually clear what the effect of privatization would be on the environment. We aim to investigate this by comparing environmental performance as measured by sulfur dioxide $\left(\mathrm{SO}_{2}\right)$ emissions for privatized and state-owned energy utilities. $\mathrm{SO}_{2}$ is a pollutant that has relatively wellunderstood abatement technologies and environmental effects making it a logical choice for examining firm behavior. We concentrate on the energy utilities industry because many of the largest emitters of $\mathrm{SO}_{2}$ are energy utilities and various governments have retained significant ownership in this sector. The energy sector makes up approximately 95 percent of Poland's total $\mathrm{SO}_{2}$ emissions (Poland Ministry of the Environment, 2007).

Beginning in the early 1990's Eastern European governments privatized many firms that were previously under state control. This provided a source of revenue for government and propelled the transition toward a market economy. While some firms were privatized, others remained under state control. Presently, governments continue to contemplate selling state-owned firms in various industries such as telecommunications and electricity genera-

\footnotetext{
${ }^{1}$ By energy utilities we are referring to electricity generating and combined heat and power plants.
} 
tion. Poland is a leading example of the approach that Eastern European governments have pursued. According to Jouret (2006), Poland has privatized ten out of its twenty-three combined heat and power (CHP) plants. Of its dedicated electricity generation plants, Poland has privatized only four and retains sole ownership of 75 percent of the electricity generation capacity (Jouret, 2006). ${ }^{2}$

Using a novel plant level data set of Eastern European energy utilities, we investigate $\mathrm{SO}_{2}$ emissions of state-owned and privatized plants between the years of 2004 and 2009 . This data set contains virtually all of the electricity generating and CHP plants larger than 50 MWth in Bulgaria, the Czech Republic, Hungary, Poland, and Romania. Approximately eleven percent of our 320 sample plants switch from state-owned to privatized during our study period. Exploiting this within-plant variation in ownership we find that, all else equal, privatized plants pollute less than state-owned plants. While some previous studies (Eskeland and Harrison, 2003; Cole, Elliott, and Strobl, 2008) utilize energy use as a proxy for emissions, we make use of actual plant level $\mathrm{SO}_{2}$ emissions as reported to The EU's Environment Agency. This can be an important difference since the correlation of energy use to $\mathrm{SO}_{2}$ emissions is only about 0.54 in our dataset.

From a policy perspective, it is useful to understand how plant ownership can potentially affect $\mathrm{SO}_{2}$ emissions. $\mathrm{SO}_{2}$ can cause acid rain, which damages aquatic ecosystems and soil quality, harms forests, and deteriorates buildings and infrastructure. In addition, $\mathrm{SO}_{2}$ contributes to respiratory problems as a local and regional air pollutant. The European Union regulates $\mathrm{SO}_{2}$ emissions because of these adverse consequences. Under several pieces

\footnotetext{
${ }^{2}$ Note that these statements were accurate at the time but Poland has since privatized more energy utilities.
} 
of legislation, including the Large Combustion Plant Directive (LCPD), member countries are obligated to monitor and report emissions and conform to the standards developed in the directive. The LCPD requires member states to limit sulfur dioxide, nitrogen oxide, and particulate matter emissions from combustion plants with a rated thermal input of 50 MWth or more, so there will be increasing pressure to reduce emissions from energy utilities. Furthermore, the EU member countries still owning a large share of their energy utilities plants, such as Poland and Romania, will undoubtedly investigate privatizing more energy utilities in the future. Our results suggest that this privatization could lead to lower $\mathrm{SO}_{2}$ emissions.

\section{Previous Literature}

The literature on privatization has been extensive over the past twenty years. There are many papers that compare financial performance of state-owned firms to firms that have been privatized. Meggison and Netter (2001) provide a summary of empirical studies that compare performance of state and private firms. These studies largely conclude that privately owned firms are more efficient and profitable than state-owned firms. There are also other studies that look at various aspects of performance of state and private firms, including the impact of ownership on performance (Frydman, Gray, Hessel, and Rapaczynski, 1999; Frydman, Hessel, and Rapaczynski, 2000).

There are few studies that compare the environmental performance of state and privatized firms. Beladi and Chao (2006) develop a theoretical model where they show that under certain conditions privatization can be harmful to the environment. Cato (2008), shows that 
privatization in a mixed market industry with high negative externalities can also be harmful to the environment. There is no direct empirical comparison of environmental performance for state-owned and private-owned firms. We do know that more productive firms tend to pollute less (Holladay, 2010) and that private firms are more productive than state-owned firms (Meggison and Netter, 2001; Dewenter and Malatesta, 2001; Brown, Earle and Telegdy, 2006). This would lead us to a hypothesis that private-owned firms pollute less than stateowned but no formal studies have been conducted. Earnhart and Lizal (2006) examine the effects of ownership structure and financial performance on environmental performance in the Czech Republic. They examine firms from a wide variety of industries and find that state ownership improves environmental performance relative to other ownership structures.

There are several studies that examine how firm ownership impacts the pollution behavior of firms. This literature compares environmental performance of firms based on foreign ownership and domestic ownership; the results are mixed. Collins and Harris (2002) find that foreign-owned plants spend more on pollution abatement technology than do domestically owned firms. Eskeland and Harrison (2003) find that foreign owned firms pollute less than domestically owned firms. In contrast, Cole, Elliott, and Strobl (2008) utilize a sample of Ghanaian firms and find that foreign ownership is associated with an increased use of electricity. The inconclusive results may stem from the fact that these studies use energy as a proxy for emissions since data on plant emissions are not readily available. Solely examining energy input ignores the differing abatement technologies among firms. Energy use would not, for example, capture the installation of scrubbers or the use of low sulfur coal.

Furthermore, a majority of studies on privatization use data on manufacturing firms 
since the largest sector that was privatized was manufacturing. Privatization of energy utilities in developing and transitional countries slowly started in the last decade but most of the energy utilities are only now being sold. The environmental impacts of privatizing energy utilities have not been studied. Studies such as Williams and Ghanadan (2006) for developing and transitional countries and Jamasb and Pollitt (2005) for the European Union summarize the current state of reforms and liberalization carried out in the electricity market. No conclusions are presented regarding electricity market reform and its impact on environment.

Several papers have investigated the link between increased environmental regulation and financial performance. The "Porter Hypothesis" states "more stringent regulations initiate innovation in companies" (Brannlund and Lundgren, 2009). According to the Hypothesis, this innovation then translates into better competitiveness and hence better profitability. However, the Porter Hypothesis has not received much theoretical or empirical support. On the contrary, several studies find evidence against the Porter Hypothesis (Brannlund and Lundgren, 2009; Rassier and Earnhart, 2010).

There are also studies that address the restructuring of regulations and the corresponding effects on electricity generation efficiency. For example, Fabrizio, Rose, and Wolfram (2007) examine the US electricity market to analyze how changing from cost-of-service regulation to market competition impacts the efficiency of investor-owned firms. They focus on estimating production functions to assess efficiency gains from restructuring and incorporate firms' cost minimization. They find that changing to more market oriented environments improves the efficiency of investor-owned electricity firms, while publicly-owned firms that were not impacted by restructuring experience little gain in efficiency; hence competition improves 
efficiency in this regulated industry. The effect of market restructuring on firms' pollution levels is not addressed.

As noted by Earnhart and Lizal (2006), liquidity constraints play a potentially important role in a plant's environmental performance. Plants with poor past and present profitability will have more difficulty obtaining external financing. Moreover, if a plant is constrained in its access to capital markets, it needs to utilize internal financing from retained profits to undertake capital investments. Thus, a plant with negative or poor profitability experiences significant liquidity constraints. There may be plants that would like to invest in pollution abatement technology but are prevented from doing so due to lack of financing. Since this constraint lessens as profitability increases, plants with greater profitability will be able to undertake desired capital investments. There is evidence from Uliasz-Bochenczyk and Mokrzycki (2007) that Polish plants were investing in desulfurization facilities during our study period so it appears that plants were in fact interested in enhancing environmental performance with capital projects. ${ }^{3}$

Uliasz-Bochenczyk and Mokrzycki (2007) examine the emissions from the Polish power industry. They note that "numerous investments in new devices in the Polish professional power industry are being carried out or the existing devices updated, $\ldots$, resulting in reduction of harmful emission into the environment." They state that Polish $\mathrm{SO}_{2}$ emissions have decreased from 1,221,992 $\mathrm{Mg}$ in 1995 to $679,849 \mathrm{Mg}$ in 2005. Also, desulfurization facilities in Poland increased from 1 to 31 between 1998 and 2005. Therefore, there is evidence that some firms in our study area were in fact investing in $\mathrm{SO}_{2}$ abatement technology during our

\footnotetext{
${ }^{3}$ We unfortunately do not have sufficient financial information to test whether or not profitability affects emissions in this paper.
} 
study period.

\section{Conceptual Framework}

Here we develop a simple conceptual framework to explain why we might expect to see differences in emissions between state-owned and privatized plants. We first assume that privatized and state-owned plants do not differ in their marginal benefit or marginal cost of emissions. From the standard theory of the firm, privately owned businesses seek to maximize profits. Hence, we assume that a privatized plant chooses the level of emissions that equates its private marginal benefit from emissions and their private marginal cost from emissions. For a given level of production, the marginal benefit from emissions is reduced emissions control costs. As noted in Earnhart and Lizal (2006), the marginal cost of emissions for a plant includes potential inefficient use of inputs, increased emission charges, and increased regulatory attention and penalties. Let $z$ represent the level of emissions. $M B(z)$ represents the marginal benefit from increased emissions. $M B(z)$ is decreasing in emissions because emissions marginal control costs increase with higher levels of control. $M C(z)$ represents the marginal cost from increased emissions, which is increasing in emissions. Then, $M B(z)=$ $M C(z)$ implicitly defines a profit-maximizing level of emissions, $z^{*}$.

Following Earnhart and Lizal (2006), we assume that state-owned plants may not necessarily be maximizing profits. Denote the level of emissions generated by a state firm as $z^{s}$

(Hypothesis 1): If emissions control costs under state ownership are higher than the profit maximizing level such that $M B\left(z^{s}\right)>M C\left(z^{s}\right)$ (excessive control costs), private own- 
H1

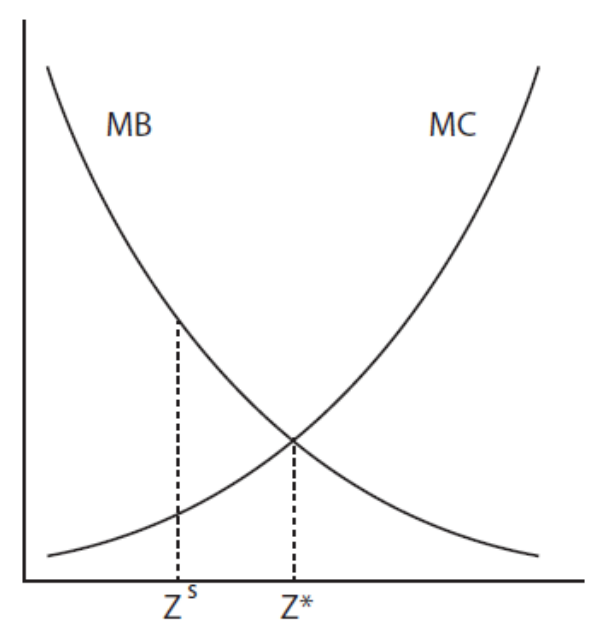

H2

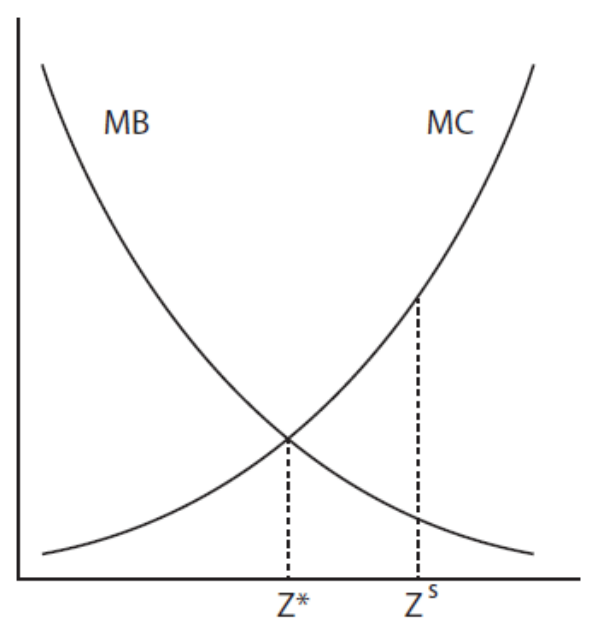

Figure 1: Hypothesis 1 and Hypothesis 2.

ership will increase emissions relative to state ownership.

(Hypothesis 2): If emissions costs under state ownership are higher than the profit maximizing level such that $M B\left(z^{s}\right)<M C\left(z^{s}\right)$ (too little control costs), private ownership will decrease emissions relative to state ownership.

In this context, differences in profit maximizing behavior are driving differences in emissions. Furthermore, emissions can conceptually be higher or lower under private ownership depending on the nature of the non-optimal decision-making by state-owned plants.

Next, we allow for the possibility that the marginal cost curves differ between state-owned and privatized plants while still assuming identical marginal benefit curves. In addition to the components of marginal cost of emissions previously mentioned, we acknowledge that state-owned and privatized plants may face different pressures from regulators and may have different preferences for environmental protection. Denote the marginal cost curve for a 
privatized plant as $M C^{p}(z)$ and the marginal cost curve for a state-owned plant as $M C^{s}(z)$. Assume that both types of plants act optimally by equating their respective marginal cost curves to their marginal benefit curves. Denote the level of emissions generated by the state plant as $z^{s}$ and the level of emissions generated by the private plant as $z^{p}$ when they are behaving optimally.

First, we examine the relationship between regulatory attention and ownership status.

(Hypothesis 3a): Suppose state-owned plants receive less regulatory attention than privatized plants. In this case, $M C^{p}(z)>M C^{s}(z)$. Then, $z^{s}>z^{p}$ and we observe higher emissions from state-owned plants.

(Hypothesis 3b): Suppose state-owned plants receive more pressure to achieve better environmental performance. In this case, $M C^{s}(z)>M C^{p}(z)$. Then, $z^{s}<z^{p}$ and we observe lower emissions from state-owned plants.

Thus, the relationship between ownership status and regulatory pressure is ambiguous.

Next, we examine the relationship between ownership status and relative concern for environmental protection. State-owned plants might have higher relative concerns for environmental protection because they are seeking to please government officials or the public. Conversely, privatized plants might have higher relative concerns for environmental protection because of public image concerns in the country of production and potentially in foreign markets.

(Hypothesis 4a): Suppose privatized plants have higher relative concern for environmental protection. This will lead the privatized plant to internalize more of the damages from emissions to society and $M C^{s}(z)<M C^{p}(z)$. Then, $z^{s}>z^{p}$ and we observe higher 
H3a, H4a

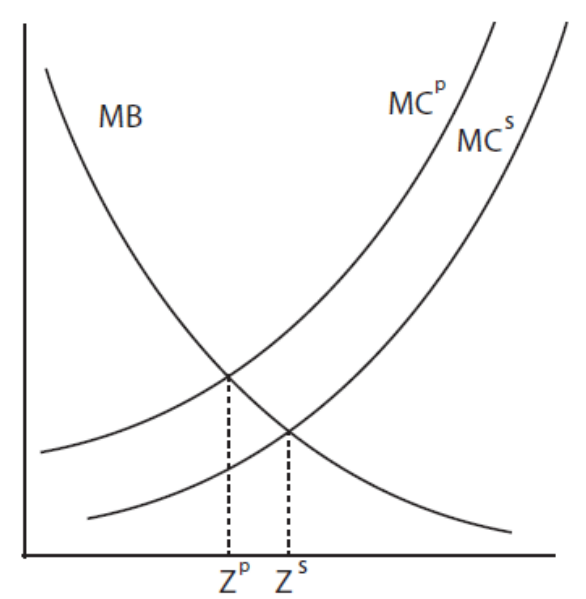

H3b, H4b

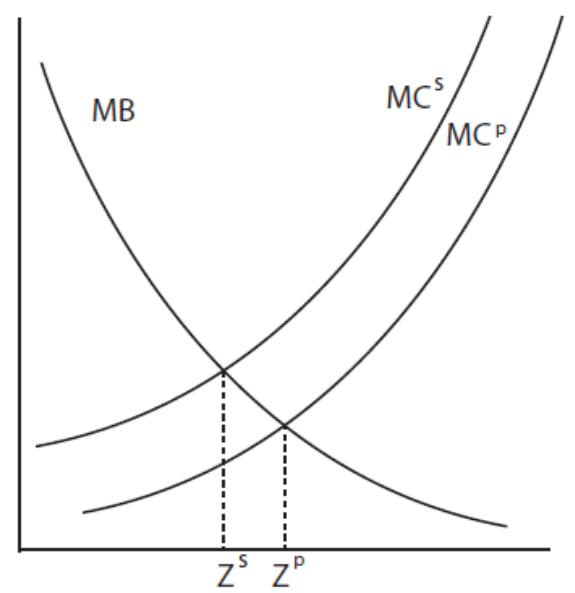

Figure 2: Hypothesis 3a, Hypothesis 3b, Hypothesis 4a, and Hypothesis $4 b$.

emissions from state-owned plants.

(Hypothesis 4b): Suppose state-owned plants have higher relative concern for environmental protection. This will lead the state-owned plants to internalize more of the damages from emissions to society and $M C^{s}(z)>M C^{p}(z)$. Then, $z^{s}<z^{p}$ and we observe lower emissions from state-owned plants.

Again, ownership status has a conceptually ambiguous effect.

Within this simple conceptual framework, we have three possible explanations for why state-owned plants would have higher emissions and three possible explanations why privatized plants would have higher emissions. Hence, it is not clear which ownership status should be conceptually associated with higher emissions. We therefore empirically investigate the relationship. 


\section{Data and EU Regulatory Background}

Prior to describing our data, we explain the EU regulatory context during our study period (2004-2009). There are two major pieces of EU legislation that affected emissions at energy utilities during the mid to late 2000's: The Large Combustion Plant Directive (LCPD / Directive 2001/80/EC) and the EU Emissions Trading System (ETS).

\subsection{LCPD}

With the goal of improving human and environmental health, the EU adopted the LCPD in October 2001, with the regulations taking effect January 2008. January 2008 is toward the end our study period but, since the legislation was passed in 2001, some plants may have begun preparing for the changes earlier in our study period. Thus, we explain the legislation in some detail to give an idea about the regulatory environment for which plants were preparing during the mid 2000's. The LCPD is a complex EU directive that requires Member States to reduce emissions of sulphur dioxide, nitrogen oxides, and particulate matter from combustion plants with a rated thermal input of 50 MWth or more (Ritchie et al., 2005). Plants with thermal input of this scale include power utilities, oil refineries, and large industrial manufacturers such as steelworks plants. "For existing plants (licensed before 1 July 1987), each Member State is able to choose between complying with emission limit values (ELVs) as set out in part A of Annexes II to VII or implementing a national emission reduction plan as defined in Article 4(6). The compliance date for existing plants is 1 January 2008" (Ritchie et al., 2005). The national emission reduction plan essentially must reduce the total annual emissions for the Member State to the same levels that would have been achieved 
by applying the ELVs to each of the Member State's existing plants in 2000. However, the Czech Republic is the only country in our sample that filed for the national reduction plan. The Czech Republic's national emission limit values are actually slightly more stringent than the LCPD values for some plants (Ritchie et al., 2005).

All new plants (licensed after July 1, 1987) must comply with the ELVs. Furthermore, plants licensed before November 27, 2002 must comply with the ELVs from part A of Annexes III to VIII, while plants licensed after November 27, 2002 must comply with more stringent ELVs described in part B of Annexes III to VII (Ritchie et al., 2005). Table 1 presents the ELVs for $\mathrm{SO}_{2}$ for new and existing plants. Note that the ELVs differ by the fuel type that is being burned. Liquid and solid fuels have much more lenient limits than natural gas.

All firms in the other countries are subject to the LCPD with several exceptions. The first exception is the so-called "limited life derogation clause." As noted by Ritchie et al. (2005), "an operator of an existing plant may be exempted from compliance with the ELVs (emission limit values) and from inclusion in a national emission reduction plan if a written undertaken was submitted to the competent authority by 30 June 2004, not to operate the plant for more than 20,000 operational hours starting from 1 January 2008 and ending no later than 31 December 2015." Thus, firms opting for this limited life derogation would be able to operate on average a little less than seven hours a day and must be completely shut-down by 2015. If run continuously for 24 hours a day, firms opting for the limited life derogation would have shut down by March of 2010. As these firms have much more lenient limits on emissions for their shortened lives, they have less incentive to install flue gas desulfurization technologies ( $F G D$, i.e. wet or dry sulfur scrubbers) or switch to low sulfur coal. 
Table 1: LCPD Emission Limit Values for SO2

\begin{tabular}{|c|c|c|c|}
\hline Fuel Type & Size of Plant & & \\
\hline Existing Plants & 50 to $100 \mathrm{MWth}$ & 100 to $300 \mathrm{MWth}$ & $>300 \mathrm{MWth}$ \\
\hline Solid Fuels & 2000 & $\begin{array}{c}2000 \text { to } 400 \\
\text { (linear decrease) }\end{array}$ & 400 \\
\hline Liquid Fuels & 1700 & $\begin{array}{c}1700 \text { to } 400 \\
\text { (linear decrease) }\end{array}$ & 400 \\
\hline Gaseous Fuels in general & 35 & 35 & 35 \\
\hline Liquefied gas & 5 & 5 & 5 \\
\hline Low calorific gases & 800 & 800 & 800 \\
\hline \multicolumn{4}{|l|}{ New Plants } \\
\hline Biomass & 200 & 200 & 200 \\
\hline Other Solid Fuels & 850 & 200 & 200 \\
\hline Liquid Fuels & 850 & $\begin{array}{c}400 \text { to } 200 \\
\text { (linear decrease) }\end{array}$ & 200 \\
\hline Gaseous Fuels in general & 35 & 35 & 35 \\
\hline Liquefied gas & 5 & 5 & 5 \\
\hline $\begin{array}{l}\text { Low calorific gases from } \\
\text { coke oven } \\
\text { Low calorific gases from }\end{array}$ & 400 & 400 & 400 \\
\hline blast furnace & 200 & 200 & 200 \\
\hline
\end{tabular}

Note: All ELVs are in mg/Nm3 
The second broad category of exceptions to the LCPD consists of derogation allowances given to several New Member States. These New Member States have treaty conditions that allow them to exempt certain plants from various ELVs for a specified time period. As noted by Ritchie et al. (2005), "the countries with the most extensive derogation allowances, as well as the only countries with derogation allowances beyond 2008, include Estonia, Lithuania, and Poland." Nonetheless, all countries will eventually be faced with the ELVs stated in the LCPD. There are several EU countries that have national ELVs that are more stringent than the LCPD ELVs. According to the information that we are able to find, most of the national ELVs for our study countries are less stringent than the LCPD ELVs.

\subsection{EU ETS}

January 1, 2005 marked the beginning of the operation of the EU ETS program in which "virtually all stationary, industrial, and electricity-generating installations within the EU" pay a price for carbon emissions (Ellerman and Buchner, 2007). Although this legislation does not directly regulate $\mathrm{SO}_{2}$ emissions, plants changing their behavior in response to carbon regulations could conceivably alter their $\mathrm{SO}_{2}$ emissions. For example, if a plant were to undergo a retrofit to switch fuel inputs from coal to natural gas or biomass, they could capture revenue by selling a carbon emissions permit, which would at the same time reduce $\mathrm{SO}_{2}$ emissions. Or, simply reducing output would reduce carbon emissions as well as $\mathrm{SO}_{2}$ emissions. Thus, we briefly overview the ETS.

As identified by Ellerman and Buchner (2007), the largest problem with the initial implementation of the EU ETS was the absence of reliable, available data at the installation 
level. Due to this data scarcity, the EU gathered data on a voluntary basis directly from the regulated sources. This data was then used to determine the allocations to the installations. While one might be suspicious of the self-reported emissions, "participants in the process reported relatively few cases of fraudulent submissions" (Ellerman and Buchner, 2007). Regardless of the cause, the May 2005 emissions data released in April and May of 2006 revealed that the number of allowances distributed to installations in 2005 exceeded those installations' emissions by about 80 billion tons (4\% of the EU cap). Subsequently, the price for first period allowances fell by one-half and second period future prices fell by one-third.

In order to reduce carbon emissions, the EU would need to allocate a shortage of emissions allowances. "Broadly speaking, this expected shortage for the EU as a whole was allocated to the EU15 and, within the EU15, to the electricity utility sector" (Ellerman and Buchner, 2007). None of the plants represented in our sample come from EU15 countries. As explained by Ellerman and Buchner (2007), all new EU10 countries (including the Czech Republic, Hungary, and Poland) were long on emissions permits in 2005. This could be a result of overallocation, lower output, or abatement. An overly generous initial allocation of permits to EU10 countries would not likely cause significant changes in $\mathrm{SO}_{2}$ emissions because plants would simply sell the excess permits. However, a reduction in output or fuel switching to abate carbon emissions could cause significant changes in $\mathrm{SO}_{2}$ emissions at EU10 plants. Bulgaria and Romania did not joint the EU until January 1, 2007.

The case of Poland again provides an illustrative example. According to Jouret (2006, p22), "for the 2005-2007 trading period, the Polish electricity sector received a significant surplus of emission rights. However, because regulations were not implemented, the emission 
trading scheme in fact still does not function in Poland." Jouret (2006) continues to explain that Poland's average emission limit for the 2008-2012 trading period will be around 60 million tons higher than the 390 million tons of forecasted annual emissions for the period. Finally, Jouret (2006) concludes that the ETS would not likely significantly affect emissions or the fuel mix in Poland.

\subsection{Plant Environmental Performance and Ownership Data}

To establish the link between privatization and $\mathrm{SO}_{2}$ emissions we construct an unbalanced panel by merging information from multiple data sources. We begin by identifying 402 energy utilities in the EU Large Combustion Plant Directive (LCPD) data in the five countries that we study: Bulgaria, Czech Republic, Hungary, Poland, and Romania. Spanning the years 2004 to 2009 and managed by the European Environment Agency, the LCPD data set contains information about $\mathrm{SO}_{2}$ emissions as well as the associated thermal input ratings and energy usage for plants that fall under the directive.

Next, we identify the ownership of each of these plants for the years of 2004-2009. This information comes from several sources. Bureau van Dijk Electronic Publishing's (BvDEP) Zephyr database is a merger and acquisition $(\mathrm{M} \& \mathrm{~A})$ database that allows users to identify deals that were done through privatization. Zephyr has information on deals and potential deals involving privatization of power generating plants and combined heat and power (CHP) plants between 1997 and 2006. This provides ownership information on 66 of the LCPD plants. For plants that are not found in the Zephyr database, we conduct an extensive internet search to find a reliable source detailing ownership information. We find either a date 
of privatization or information that the plant was still state-owned at the end of our study period. Reliable sources include published news articles, governmental and non-governmental research studies, and official websites of the energy utilities. ${ }^{4}$ Plants that were built privately and never state-owned are removed from the sample. Subsequently, we are left with a sample of 320 energy utility plants on which to base our analysis. Table 2 gives a comparison of the number of plants in the LCPD data with the number of plants in our sample from each country. For our six year panel, we have a total of 1,920 plant-year observations on the ownership variable, 1,683 observations on energy input, 1,811 observations on plant capacity, and 1,851 observations on $\mathrm{SO}_{2}$ emissions. We have six years of $\mathrm{SO}_{2}$ emissions for 286 plants, five years of $\mathrm{SO}_{2}$ emissions for 14 plants, four years of $\mathrm{SO}_{2}$ emissions for five plants, and three years of $\mathrm{SO}_{2}$ emissions for 15 plants, which means that 89 percent of our firms have no missing information on the dependent variable.

Table 3 shows that, of the plant-year level observations, roughly one-quarter are privately owned and three-quarters are state-owned. Note that the ownership composition of the sample evolves over the six years. In this panel, 52 plants are always privately held and 231 are always state-owned. As such, these two groups of firms do not show any change in privatization status in our panel. A third group of 37 plants do see a switch in their ownership status during our six-year panel. These are the plants that were privatized during 2005-2009. 23 plants were privatized in 2005, six plants were privatized in each of 2006 , five in 2007, and the remaining three were privatized in 2008 and 2009.

As shown in Table 4, nearly half of the sample's plant-year observations come from Romania. One-quarter of our sample comes from Poland. Hungary and Bulgaria each

\footnotetext{
${ }^{4} \mathrm{~A}$ complete list of ownership data sources is available from the authors upon request.
} 
Table 2: Energy Utility Plants in LCPD vs Sample

\begin{tabular}{l||cc}
\hline \hline Country: & LCPD & Sample \\
\hline \hline Bulgaria & 36 & 36 \\
Czech Rep. & 86 & 13 \\
Hungary & 38 & 34 \\
Poland & 80 & 78 \\
Romania & 162 & 159 \\
Total & 402 & 320 \\
\hline \hline
\end{tabular}

contribute approximately ten percent of the sample plants and plants in the Czech Republic comprise the final four percent of the sample. Each country has some state-owned plants and some privately owned plant-year observations.

Our main dependent variable of interest is the annual sulfur dioxide $\left(\mathrm{SO}_{2}\right)$ emissions (in kilotons) of each energy utility plant provided in the LCPD data. In our analysis we control for the energy input $(E I)$ of each plant where energy input is measured in petajoules. The LCPD data also provides the rated maximum thermal input (MWTH) for each plant, and a dummy (OptOut) variable which is 1 if a plant opted out of the LCPD emissions limits under the limited life derogation clause and 0 if it did not. We construct a dummy state versus private $(S v P)$ ownership variable which is 1 if the plant is owned by a private firm in year $t$ and 0 if a plant was under state ownership. Finally, we construct a dummy variable for $\mathrm{CHP}$ vs power plant $(C H P)$ which is 1 if the plant is a $\mathrm{CHP}$ and 0 if it is a power plant because these two types of plants do systematically differ in their observable characteristics and activities. For example, power plants are over four times larger than CHP's in terms of MWth rating in our sample. 
Table 3: Ownership by year

\begin{tabular}{c||ccc}
\hline \hline Year: & Private & State & Total \\
\hline \hline $\mathbf{2 0 0 4}$ & 52 & 268 & 320 \\
$\mathbf{2 0 0 5}$ & 75 & 245 & 320 \\
$\mathbf{2 0 0 6}$ & 81 & 239 & 320 \\
$\mathbf{2 0 0 7}$ & 86 & 234 & 320 \\
$\mathbf{2 0 0 8}$ & 87 & 233 & 320 \\
$\mathbf{2 0 0 9}$ & 89 & 231 & 320 \\
Total & 470 & 1450 & 1920 \\
\hline \hline
\end{tabular}

Note: There are 1920 plant-year observations.

As previously mentioned, the LCPD limits emissions from combustion plants of $50 \mathrm{MWth}$ or larger. The initial date of compliance for the LCPD was January 1, 2008. Plants would not choose to reduce emissions before they are so required, unless it leads to higher profits by doing so. Therefore, we do not anticipate that many firms would have undertaken the capital investment necessary to reduce emissions prior to the compliance date solely for LCPD compliance. However, countries were required to begin reporting emissions information beginning in 2004 so it is plausible that some forward looking plants did choose to abate some emissions at that time. Also, we expect that plants might behave differently with regards to pollution once they have made the decision to opt out of the LCPD. For these reasons, we do include an indicator variable in our analysis to control for any possible difference in the opted out plants (Opt Out). Table 5 shows the summary statistics for all variables.

Table 6 compares plant characteristics by ownership status. There are significant differences in the energy input, thermal rating of plants $(M W T H)$, LCPD opt out percentages, and $\mathrm{SO}_{2}$ emissions between state-owned and privately held plants. Privatized plants are 
Table 4: Ownership by country

\begin{tabular}{l||ccc}
\hline \hline Country: & Private & State & Total \\
\hline \hline Bulgaria & 72 & 144 & 216 \\
Czech Republic & 52 & 26 & 78 \\
Hungary & 107 & 97 & 204 \\
Poland & 213 & 255 & 468 \\
Romania & 26 & 928 & 954 \\
Total & 470 & 1450 & 1920 \\
\hline \hline
\end{tabular}

Note: There are 1920 plant-year observations.

Table 5: Summary Statistics

\begin{tabular}{l||ccccc}
\hline \hline Variable: & Obs. & Mean & Std. Dev. & Min & Max \\
\hline \hline SO $_{2}$ & 1851 & 5.795 & 22.470 & 0.00 & 337.205 \\
Energy Input & 1683 & 8.368 & 22.110 & 0.0 & 280.973 \\
MWTH & 1811 & 659.589 & 1139.023 & 0 & 12600 \\
Opt Out & 1914 & .213 & .410 & 0 & 1 \\
\hline \hline
\end{tabular}

Note: Energy Input is in Petajoule,

Table 6: Characteristics by Ownership

\begin{tabular}{l||cccc}
\hline \hline Variable: & State-Owned & Private-Owned & t-test & Obs. \\
\hline \hline SO $_{2}$ & 5.28 & 7.37 & $-1.76^{*}$ & 1851 \\
Energy Input & 7.21 & 12.10 & $-4.40^{* * *}$ & 1683 \\
MWTH & 592.10 & 868.02 & $-4.72^{* * *}$ & 1811 \\
Opt Out & 0.23 & 0.17 & $2.74^{* * *}$ & 1914 \\
\hline \hline
\end{tabular}

Note: Means of all values are given.

Energy Input is in Petajoule. * significant at 10\%, $* *$ significant at $5 \%, * * *$ significant at $1 \%$. 
over 47 percent larger in terms of thermal rating and use about 70 percent more fuel than state-owned plants on average. Thus, private-owned plants may be operating with less excess capacity than state plants. A larger percentage of state-owned plants have opted out of the LCPD emissions limits than privately owned plants. Finally, without controlling for any plant characteristics, there is a significant difference in mean $\mathrm{SO}_{2}$ emissions with privately owned plants emitting about 40 percent more than state-owned plants on average.

Figure 3 plots means of $\mathrm{SO}_{2}$ emission for state-owned plants and private plants for the six years. ${ }^{5}$ In 2004, private plants have a much higher $\mathrm{SO}_{2}$ mean than state-owned plants but this gap decreases substantially in subsequent years until there is almost no gap in 2009. Interestingly, the mean for privatized plants is continuously decreasing with the exception of the increase in 2006 from 2005 levels. The mean for state-owned firms increases over the first several years until 2006, when it begins to decrease. To the extent that privatized plants would behave differently in reaction to the financial incentives of the EU ETS, its implementation may have been a contributing factor to plants in the three EU10 countries in our sample reducing their $\mathrm{SO}_{2}$ emissions in 2005.

\section{$5 \quad$ Empirical Methodology}

In the conceptual framework, we identify three reasons why state-owned plants might have higher emissions than privatized plants and three reasons why privatized plants might have higher emissions than state-owned plants. We aim to empirically investigate the link between ownership status and environmental performance. We measure environmental performance

\footnotetext{
${ }^{5}$ Note that this figure includes all private and state-owned plants in each year of the sample and is not focusing exclusively on the plants that switch ownership during the study period.
} 


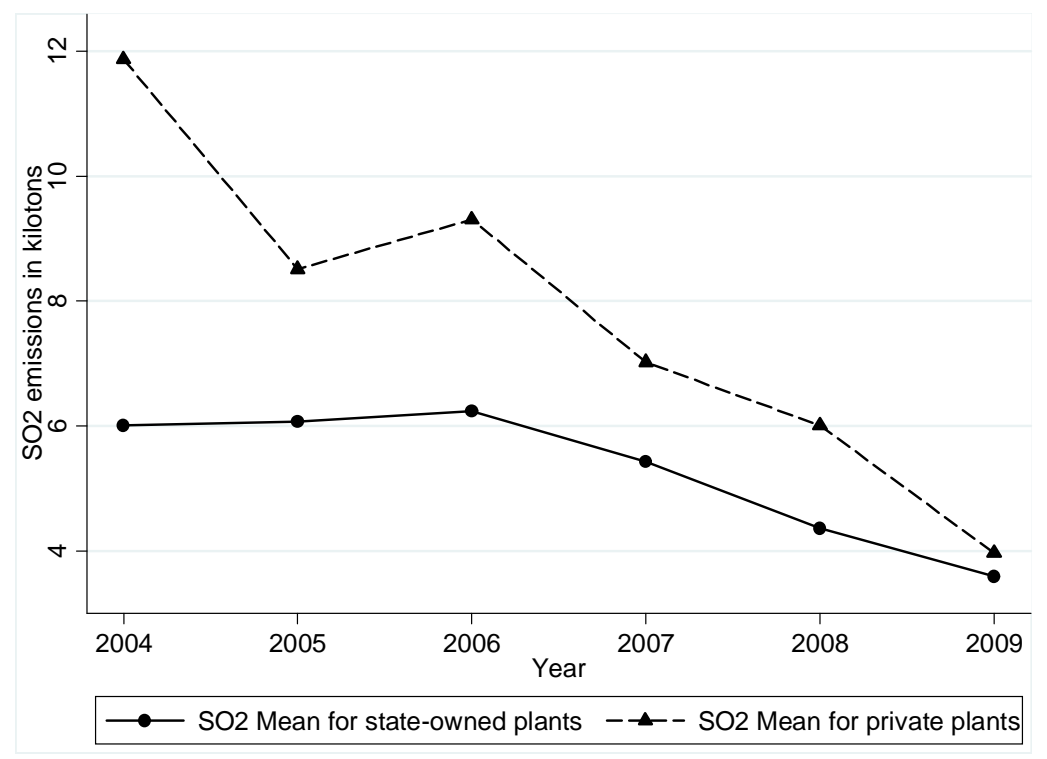

Figure 3: Mean $\mathrm{SO}_{2}$ emissions for state-owned and privately-owned plants by year.

using both aggregate $\mathrm{SO}_{2}$ emissions and $\mathrm{SO}_{2}$ emissions per unit of energy (EI). Presumably, policy-makers would be interested in both measures of environmental performance since they are concerned with both the amount of environmental damage and the concentration of $\mathrm{SO}_{2}$ emissions at individual plants. The amount of environmental damage will depend mainly on aggregate emissions since $\mathrm{SO}_{2}$ is a regional pollutant and degradation will be determined by the total amount of $\mathrm{SO}_{2}$ rather than the ratio of $\mathrm{SO}_{2}$ to energy input. The concentration of $\mathrm{SO}_{2}$ at individual plants will be determined by relative emissions if energy input is proportional to the amount of air coming through the plants' smokestacks. Similarly, Earnhart and Lizal (2006) utilize relative emissions as measured by emissions per unit of output as a proxy for emissions concentration.

$\mathrm{SO}_{2}$ emissions has a highly positively skewed distribution, so we utilize a log transformation for our dependent variable. We also log the non-indicator independent variables 
to provide an elasticity interpretation on these coefficients. Thus, we specify the following regression equations to examine the association between private versus state ownership and $\mathrm{SO}_{2}$ emissions.

$$
\ln \left(S O_{2 i t}\right)=\beta_{0}+\beta_{1} S v P_{i t}+\beta_{2} \ln \left(E I_{i t}\right)+\beta_{3} C D_{i t}+\beta_{4} \text { OptOut }+\beta_{5} C H P+\alpha_{i}+\varepsilon_{i t}
$$

and

$$
\ln \left(S O_{2} / E I\right)_{i t}=\beta_{0}^{r}+\beta_{1}^{r} S v P_{i t}+\beta_{2}^{r} C D_{i t}+\beta_{3}^{r} O p t O u t+\beta_{4}^{r} C H P+\alpha_{i}+\varepsilon_{i t}
$$

where

$$
S v P_{i t}=\frac{1 \quad \text { if plant } i \text { is a privatized plant at time } t \text { and }}{0 \text { if plant } i \text { is a state }- \text { owned plant at time } t .}
$$

Energy input and thermal rating (mwth) are highly collinear since plants with a larger thermal capacity will logically burn more fuel. In fact, the correlation is 0.93 . Since emissions should theoretically depend on the actual amount of fuel burned rather than the capacity of the plant, we utilize energy input as our control. We control for LCPD opt out status and differences between CHP and power plants. Finally, we control for differences across countries with a set of country dummies $\left(C D_{i t}\right)$. Unobservable plant-specific effects are represented by $\alpha_{i}$. If there is 0 correlation between the $\alpha_{i}$ and the explanatory variables, then both OLS and random effects are consistent estimators. If, however, the explanatory variables and the $\alpha_{i}$ are correlated, then OLS and random effects are inconsistent estimators 
and we should estimate using fixed effects. Thus, we would hesitate to utilize random effects or OLS estimation if we think there is some unobserved variable that is correlated with our privatization variable and also raises or lowers emissions. There certainly could be unobserved plant specific characteristics related to the privatization process that are correlated with the level of emissions so we prefer to utilize a fixed-effects estimator from a conceptual standpoint. $^{6}$

There are two potential sources of endogeneity that could bias results if they are ignored. First, there may be endogeneity from omitted variables that vary across plants. We may be concerned that there is some unobserved factor that is causing plants to be selected for privatization and is also correlated with $\mathrm{SO}_{2}$ emissions. For example, perhaps only the plants with better potential for emissions improvement are privatized and this potential would not change throughout the six years of the panel. In this scenario, the fixed effects model adequately controls for the unobserved heterogeneity. However, there might also be endogeneity from omitted variables that vary within plants and across time. For example, suppose a country decided to offer 20 plants for privatization in 2006. Furthermore, suppose none of the 20 plants had installed scrubbers prior to 2006. Suppose that 10 of these plants then install scrubbers in 2007 . Then, in 2008 , these 10 plants were privatized because they became more attractive for potential bidders with the scrubbers already installed. $\mathrm{SO}_{2}$ emissions at these 10 plants in 2008 and subsequent years decrease relative to 2006 (and perhaps 2007) simply because the abatement technology was installed right before privatization occurred. In this hypothetical example, the fixed effects model would not adequately control for un-

\footnotetext{
${ }^{6}$ For example, we do not have financial information about the plants which may well be correlated with privatization and emissions.
} 
observed heterogeneity since the omitted variable, investment in abatement technology, is changing throughout the panel. To address this potential source of endogeneity, we utilize an instrumental variables approach as a robustness check.

For our instrumental variable we construct a country political variable using the PARLINE database on national parliaments. ${ }^{7}$ For each country we collect information on the number of elected officials in the government by political association. We then classify each political party as either pro or anti-privatization. In general, the pro European Union centerright parties are in strong favor of privatization, whereas the center-left governments are in favor of slow privatization with keeping many of the strategic state-owned firms, such as utilities, in government's control or are completely anti-privatization. We define our political variable as percentage of center-right seats held by officials in a given county in a given year. If the country has two chambers of government then we first calculate the percentage of center-right seats held by officials in each chamber and then we average the two. This way we obtain percentage of government that is pro privatization for each year in each country. Elections were usually held every few years and this impacted privatization. For example, the Polish privatization program was held back once the euro-skeptic, center-left government took over in 2005. In October 2007, a center-right government won the election and privatization programs were renewed starting 2008.

Because of the differences in political parties' economic ideology and the direct control the majority party of a government has on privatization, we believe that our IV is a strong predictor of privatization taking place. At the same time political control should have no impact on plant level emissions. As we stated before, the reduction of emissions was driven

\footnotetext{
${ }^{7}$ The data was downloaded in June 2012 from http://www.ipu.org/parline-e/parlinesearch.asp
} 
by the European Union and less so by individual governments. In our sample of countries, the pro environment green parties were never in serious contention for government control. Czech Republic had the highest number of green party government seats with three percent in the Chamber of Deputies during the 2006 election. The higher representation of green candidates in the Czech Republic may be related to why the Czech Republic was the only country in our sample to file a national reduction plant that was slightly more stringent than the LCPD.

\section{Results}

We have a panel of six years on privatization status, energy usage, plant size, and $\mathrm{SO}_{2}$ emissions. We estimate equations (1) and (2) using the three standard panel estimators of pooled OLS, random effects, and fixed effects. The model test statistics are shown in Tables 7 (estimates for Equation (1)) and 8 (estimates for Equation (2)). The F-test for plantspecific effects shows significant individual effects in each of our specifications. Thus, we do not report the pooled OLS results since they are not consistent. A Hausman test indicates that random effects results are not consistent in specification $(I I)$. Thus, we utilize the fixed effects estimates as our baseline but also present the random effects results in Tables 7 and 8 for comparison. The random effects results can also be informative since we can test for differences in emissions based upon characteristics that do not vary within a firm throughout the panel, such as opt-out status and type of plant, power or CHP. 
Table 7: Fixed Effects (FE) and Random Effects (RE) Results (Aggregate Emissions)

\begin{tabular}{|c|c|c|c|c|c|}
\hline $\ln \mathrm{SO}_{2}$ emissions & $(I-F E)$ & $(I I-F E)$ & $(I I I-R E)$ & $(I V-R E)$ & $(V-R E)$ \\
\hline $\mathbf{S v P}_{i t}$ & $\begin{array}{c}-0.449^{* * *} \\
(0.168)\end{array}$ & $\begin{array}{c}-0.547^{* * *} \\
(0.205)\end{array}$ & $\begin{array}{c}-0.430^{* * *} \\
(0.164)\end{array}$ & $\begin{array}{c}-0.537^{* * *} \\
(0.181)\end{array}$ & $\begin{array}{c}-0.438^{* * *} \\
(0.183)\end{array}$ \\
\hline ln Energy Input ${ }_{i t}$ & & $\begin{array}{c}0.727^{* * *} \\
(0.181)\end{array}$ & & $\begin{array}{c}0.908^{* * *} \\
(0.128)\end{array}$ & $\begin{array}{c}0.877^{* * *} \\
(0.130)\end{array}$ \\
\hline Opt Out ${ }_{i}$ & & & & & $\begin{array}{l}-0.270 \\
(0.493)\end{array}$ \\
\hline $\mathbf{C H P}_{i}$ & & & & & $\begin{array}{c}-1.338^{* * *} \\
(0.385)\end{array}$ \\
\hline no. of. obs. & 1319 & 1230 & 1316 & 1230 & 1227 \\
\hline Overall $\mathbf{R}^{2}$ & 0.004 & 0.557 & 0.200 & 0.614 & 0.619 \\
\hline Hausman p-value & 0.904 & 0.000 & & & \\
\hline F-test p-value for FE & 0.008 & 0.000 & & & \\
\hline
\end{tabular}

Note: ${ }^{*}$ significant at $10 \%,{ }^{* *}$ significant at $5 \%,{ }^{* * *}$ significant at $1 \%$. Standard Errors in parentheses are clustered at plant level and are robust.

Table 8: Fixed Effects (FE) and Random Effects (RE) Results (Relative Emissions)

\begin{tabular}{l||ccc}
\hline \hline $\ln \mathrm{SO}_{2}$ emissions per Energy & $(V I-F E)$ & $(V I I-R E)$ & $(V I I I-R E)$ \\
\hline \hline $\mathbf{S v P}_{i t}$ & $-0.529^{* * *}$ & $-0.547^{* * *}$ & $-0.465^{* * *}$ \\
& $(0.205)$ & $(0.180)$ & $(0.179)$ \\
& & & -0.275 \\
Opt Out & & & $(0.382)$ \\
& & & $-1.137^{* * *}$ \\
$\mathbf{C H P}_{i}$ & & & $(0.276)$ \\
& & & 1227 \\
& & 1230 & 0.189 \\
no. of. obs. & 1230 & 0.166 & \\
Hausman p-value & 0.002 & & \\
F-test p-value for FE & 0.912 & & \\
\hline \hline
\end{tabular}

Note: ${ }^{*}$ significant at $10 \%,{ }^{* *}$ significant at $5 \%, * * *$ significant at $1 \%$. Standard Errors in parentheses are clustered at plant level and are robust. 


\subsection{Fixed Effects Results}

When we estimate a fixed-effects model, we are identifying the effect of privatization from the 37 plants that switch ownership during the study period. The coefficient on our main variable of interest, $S v P$, is negative and statistically significant in all specifications. That is, privatization is associated with decreased emissions both in an absolute sense and on a relative basis. When we do not control for the amount of energy consumed by a plant in specification $(I)$, switching from state to private ownership is associated with a decrease in aggregate $\mathrm{SO}_{2}$ emissions of around 45 percent. For our preferred specification $(I I)$, where we do control for the amount of energy consumed by a plant, privatization is associated with a decrease in $\mathrm{SO}_{2}$ emissions of around 55 percent. $^{8}$ For specification $(V I)$, privatization is associated with a 53 percent reduction in relative emissions. ${ }^{9}$

\subsection{Random Effects Results}

When we estimate a random effects model, we are identifying the effect of privatization both from the variation within plants that switch ownership and from the variation across all sample plants. We note that the random effects results are qualitatively similar to the fixed effects results. $S v P$ is statistically significant in all specifications with an estimated scale that is similar to the fixed effects regressions for both absolute and relative emissions. Opt out status is not significant so it does not appear that $\mathrm{SO}_{2}$ emissions are being impacted by plants deciding to opt out of LCPD regulations during the study period. Recall that power

\footnotetext{
${ }^{8}$ Specification $(I I)$ is preferred to specification $(I)$ on the basis of a Wald test.

${ }^{9}$ As a robustness check, we also split the sample into two groups, CHP's and power plants. Fixed effects regressions on both subsamples produce negative and significant coefficients on $S v P$.
} 
plants are over four times larger than CHP's in this sample. Even after controlling for the amount of energy utilized, CHP's emit significantly less $\mathrm{SO}_{2}$.

\subsection{Results}

Table 9 gives IV results for absolute emissions and Table 10 shows IV results for relative emissions. We note that the sign on $S v P$ is negative and significant for all IV specifications. We find that the IV estimates are significantly different from their non-IV counterparts in specifications $(I X),(X I I)$, and $(X I V)$. Here, the IV estimates are preferred since the nonIV estimates are inconsistent. For the other specifications, we fail to reject the null that there is no systematic difference between the IV and non-IV estimates. For these specifications, we prefer the non-IV estimates because they are consistent and more efficient than the IV estimates. A Wald Test between specifications $(I X)$ and $(X)$ confirms that energy input is an important independent variable. Hence, specification $(I I)$ remains our overall preferred specification. ${ }^{10}$

\section{Discussion}

Our results are consistent with Hypotheses 2, 3a, and 4a and inconsistent with Hypotheses 1, 3b, and 4b. Since Hypothesis 2 is framed in terms of plants making changes once privatized, we more closely examine the 37 plants that were privatized during our study period to see whether the change in ownership results in changes that are consistent with the hypothesis. Table 11 displays the distribution of these 37 plants across the sample countries and Table 12

\footnotetext{
${ }^{10}$ First stage results for all IV regressions are available upon request.
} 
Table 9: Fixed Effects (FE) and Random Effects (RE) IV Results (Aggregate Emissions)

\begin{tabular}{|c|c|c|c|c|c|}
\hline $\ln \mathrm{SO}_{2}$ emissions & $(I X-F E)$ & $(X-F E)$ & $(X I-R E)$ & $(X I I-R E)$ & $(X I I I-R E)$ \\
\hline $\mathbf{S v P}_{i t}$ & $\begin{array}{c}-8.923^{* *} \\
(4.403)\end{array}$ & $\begin{array}{c}-9.183^{* *} \\
(4.297)\end{array}$ & $\begin{array}{c}-8.250 * \\
(4.327)\end{array}$ & $\begin{array}{c}-9.161^{* *} \\
(3.878)\end{array}$ & $\begin{array}{c}-9.271^{* *} \\
(3.896)\end{array}$ \\
\hline ln Energy Input It $_{i t}$ & & $\begin{array}{c}0.704^{* * *} \\
(0.078)\end{array}$ & & $\begin{array}{c}0.736^{* * *} \\
(0.069)\end{array}$ & $\begin{array}{c}0.728^{* * *} \\
(0.070)\end{array}$ \\
\hline Opt Out ${ }_{i}$ & & & & & $\begin{array}{l}-0.300 \\
(1.739)\end{array}$ \\
\hline $\mathrm{CHP}_{i}$ & & & & & $\begin{array}{l}-0.118 \\
(1.905)\end{array}$ \\
\hline no. of. obs. & 1319 & 1230 & 1319 & 1230 & 1227 \\
\hline Overall $\mathbf{R}^{2}$ & 0.004 & 0.033 & 0.041 & 0.165 & 0.161 \\
\hline Hausman p-value for IV & 0.054 & 0.132 & 0.637 & 0.018 & 0.1144 \\
\hline F-test p-value for $F E$ & 0.000 & 0.000 & & & \\
\hline
\end{tabular}

Note: * significant at $10 \%,{ }^{* *}$ significant at $5 \%, * * *$ significant at $1 \%$.

Standard Errors in parentheses are clustered at plant level and are robust.

Table 10: Fixed Effects (FE) and Random Effects (RE) IV Results (Relative Emissions)

\begin{tabular}{l||ccc}
\hline \hline ln $\mathrm{SO}_{2}$ emissions per Energy & $(X I V-F E)$ & $(X V-R E)$ & $(X V I-R E)$ \\
\hline \hline $\mathbf{S v P}_{i t}$ & $-8.990^{* *}$ & $-9.062^{* *}$ & $-9.147^{* *}$ \\
& $(4.272)$ & $(3.983)$ & $(3.994)$ \\
Opt Out & & & -0.312 \\
& & & $(0.922)$ \\
CHP $_{i}$ & & & 0.308 \\
& & & $(1.165)$ \\
\hline no. of. obs. & 1230 & 1230 & 1227 \\
Overall R & & 0.024 & 0.022 \\
Hausman p-value for IV & 0.002 & 0.332 & 0.576 \\
F-test p-value for FE & 0.000 & & \\
\hline \hline
\end{tabular}

Note: $*$ significant at $10 \%, * *$ significant at $5 \%, * * *$ significant at $1 \%$.

Standard Errors in parentheses are clustered at plant level and are robust. 
Table 11: Country Distribution of Plants that Switch Ownership

\begin{tabular}{l||cc}
\hline \hline Country: & Number of Switching Plants & (Percent) \\
\hline \hline Bulgaria & 11 & $(29.73)$ \\
Czech Republic & 8 & $(21.62)$ \\
Hungary & 3 & $(8.11)$ \\
Poland & 11 & $(29.73)$ \\
Romania & 4 & $(10.81)$ \\
Total & 37 & $(100)$ \\
\hline \hline
\end{tabular}

gives characteristics of these 37 plants before and after privatization. Recall that Hypothesis 2 states that state-owned plants are acting inefficiently by spending too little money on control costs. In this story, private ownership increases profits by reducing emissions. The reduction in emissions makes more efficient use of inputs, decreases emission charges, and decreases regulatory attention and penalties. According to Table 12, this does seem to be a likely explanation as mean $\mathrm{SO}_{2}$ emissions are significantly reduced by over 70 percent after these 37 plants are privatized. At the same time, the point estimate of mean energy input is only cut by approximately 20 percent when plants are privatized, and this is not a statistically significant decrease. Thus, these plants are not using significantly less energy but they are polluting less. Furthermore, the mean size of the privatized plants $(M W T H)$ is not significantly reduced with privatization, so it is not simply a case of private owners buying the plants and dismantling them.

Hypothesis 3a proposes that state-owned plants are acting optimally but are not getting as much regulatory pressure as privatized plants. Privatized plants might face extra regulatory scrutiny because they don't have the same political connections or because the state 
Table 12: Characteristics of Plants That Were Privatized During Years of 2004-2009: Before and After Privatization

\begin{tabular}{l||cccc}
\hline \hline Variable: & State-Owned (Before) & Private-Owned (After) & t-test & Obs. \\
\hline \hline SO $_{2}$ & 9.03 & 2.82 & $2.11^{* *}$ & 214 \\
Energy Input & 7.62 & 6.00 & 1.08 & 166 \\
\multirow{2}{*}{ MWTH } & 671.10 & 574.62 & 0.87 & 210 \\
\hline \hline
\end{tabular}

Note: Means of all values are given. Energy Input is in 10000's GJ.

* significant at $10 \%,{ }^{*}$ significant at $5 \%, * * *$ significant at $1 \%$.

expected a priori for the privatized plants to be worse environmental performers. In this case, we examine our full sample because both within and between variation is relevant for this hypothesis. Ideally we would have some information about the frequency or severity of penalties levied against state and private owned plants. However, in absence of such information, the opt-out variable does potentially convey some useful information. Revisiting Table 6 , we see that state-owned plants are significantly more likely to opt-out of the LCPD regulations than private-owned plants. While this is purely descriptive and does not control for other differences between state and privatized plants, state-owned plants are nearly twice as likely to opt out of the LCPD under the limited life derogation clause than are privatized plants. If state-owned plants truly did not face much regulatory oversight, we might expect very few of the plants to opt-out of the LCPD. That is, even if the state-owned plants were severely polluting, we might expect them to continue to operate with the regulators ignoring the pollution. We suspect that the admittance of these nations to the EU in mid 2000's negated much of the regulation advantage that state-owned plants had held, if there ever was one. Recall that Poland, Czech Republic, and Hungary joined the EU in 2004 while Bulgaria and Romania joined the EU in 2007. 
Finally, Hypothesis 4a posits that privatized plants are again opting optimally and have more relative concern for environmental protection. Privatized plants may have more relative concern for environmental protection because of dynamic concerns. For example, the owner of a privatized plant that achieves admirable environmental performance may have more success in acquiring more plants in the future because the state will regard them as less environmentally risky. While we cannot rule out this possibility, we find it to be the least likely explanation of the three.

\section{Conclusion}

Eastern European countries continue to reform their energy utilities markets and privatization continues to be a focal point of the reforms. To understand the full impact of privatization policies, we must understand how privatized firms differ from their state-owned counterparts. We investigate the environmental performance as gauged by $\mathrm{SO}_{2}$ emissions for Eastern European energy utilities plants between the years of 2004 and 2009. Controlling for both observable and unobservable plant characteristics, we find that privatized energy utilities plants emit less $\mathrm{SO}_{2}$ than state-owned plants.

By exploiting within plant variation, we find that privatized plants annually emit around 55 percent less $\mathrm{SO}_{2}$ than state-owned plants on average. Compared with an overall sample mean annual $\mathrm{SO}_{2}$ emissions of approximately six kilotons, this estimated scale of the difference in $\mathrm{SO}_{2}$ emissions based upon ownership status is environmentally significant. The adverse effects of $\mathrm{SO}_{2}$ are well known and include inducing respiratory problems and contributing to acid rain. Thus, an annual reduction of over three kilotons of $\mathrm{SO}_{2}$ emissions can 
have noticeable impacts, especially on a local scale. This should likely give some comfort to citizens of these Eastern European countries that are concerned about the environmental performance of newly privatized energy utilities plants.

Our novel data set combines ownership information with $\mathrm{SO}_{2}$ emissions and energy use measures. We capture a substantial majority of the energy utilities plants in Bulgaria, Czech Republic, Hungary, Poland, and Romania. This is the first study that we are aware of that investigates emissions for these countries based upon privatization status. ${ }^{11}$

Instead of using energy usage as a proxy for emissions, we utilize actual $\mathrm{SO}_{2}$ emissions as reported to the EU under the Large Combustion Plant Directive. We can then employ energy usage as an important explanatory variable in our regression analyses. Furthermore, using energy input as a proxy for $\mathrm{SO}_{2}$ emissions could be misleading since there are several other significant predictors of emissions aside from energy, as we show in our analysis.

\section{References}

1. Beladi, Hamid and Chao, Chi-Chur., 2006. "Does privatization improve the environment?" Economics Letters, Vol 93, 343-347.

2. Brannlund, R, \& Lundgren, T 2009, 'Environmental Policy without Costs? A Review of the Porter Hypothesis', International Review of Environmental and Resource Economics, 3, 2, pp. 75-117, EconLit, EBSCOhost, viewed 24 June 2011.

3. Bureau van Dijk Electronic Publishing. (n.d.). Retrieved November 2007, from Zephyr Database: https://zephyr2.bvdep.com/version-201268/Home.serv?product=zephyrneo

\footnotetext{
${ }^{11}$ A previously mentioned exception, Earnhart and Lizal (2006) include only firms from the Czech Republic.
} 
4. Cato, Susumu, 2008. "Privatization and the Environment." Economics Bulletin, Vol. 12, No. 19 pp. 1-10.

5. Cole, Matthew A., Elliott, Robert J. R., and Strobl, Eric. 2008. "The environmental performance of firms: The role of foreign ownership, training, and experience." Ecological Economics 65, pp. 538-546.

6. Collins, Alan, and Harris, Richard I. D., 2002. "Does Plant Ownership Affect the Level of Pollution Abatement Expenditure?" Land Economics, Vol. 78, No. 2, pp. 171 189.

7. Dewenter, Kathryn and Malatesta, Paul H., 2001. "State-Owned and Privately Owned Firms: An Empirical Analysis of Profitability, Leverage, and Labor Intensity." The American Economic Review, Vol. 91, No. 1, pp. 320-334.

8. Earnhart, Dietrich and Lizal, Lubomir, 2006. "Effects of ownership and financial performance on corporate environmental performance." Journal of Comparative Economics 34, pp. 11-129.

9. European Environment Agency. EU Large Combustion Plant Directive Data. Accessed June 2010. Available at: http://www.eea.europa.eu/themes/air/air-emissions-data.

10. Eskeland, G.S., and Harrison, A.E., 2003. Moving to greener pastures? Multinational and the pollution haven hypothesis." Journal of Development Economics 70, 1-23.

11. Fabrizio, Kira R., Rose, Nancy L., and Wolfram, Catherine D. 2007. "Do Markets Reduce Costs? Assessing the Impact of Regulatory Restructuring on US Electric Generation Efficiency." American Economic Review, Vol. 97(4), 1250-1277. 
12. Frydman, R., Gray, C., Hessel, M., and Rapaczynski, A., 1999. "When does privatization work? The impact of private ownership on corporate performance in the transition economies", The Quarterly Journal of Economics, November 1999.

13. Frydman, Roman, Hessel, Marek P., and Rapaczynski, Andrzej,. 1998. "Why Ownership Matters? Entrepreneurship and the Restructuring of Enterprises in Central Europe." Columbia Law School, Law-Econ Working Paper No. 172. Available at SSRN: http://ssrn.com/abstract=194574 or doi:10.2139/ssrn.194574

14. Holder, Stuart. 2000. "Privatisation and Competition: The Evidence from Utility and Infrastructure Privatisation in the United Kingdom." Privatisation, Competition and Regulation. OECD Centre for Co-operation with Non-Members, Advisory Group on Privatisation. OECD Publications Service. Paris, France.

15. Holladay, James Scott., 2010. "Are Exporters Mother Nature's Best Friends?" Available at SSRN: http://ssrn.com/abstract=1292885

16. IPU PARLINE database on national parliaments. Retrieved June 2012 from: http://www.ipu.org/par e/parlinesearch.asp

17. J. David Brown \& John S. Earle \& Almos Telegdy, 2006. "The Productivity Effects of Privatization: Longitudinal Estimates from Hungary, Romania, Russia, and Ukraine," Journal of Political Economy, University of Chicago Press, vol. 114(1), pages 61-99, February.

18. Jamasb, Tooraj and Pollitt, Michael. 2005. "Electricity Market Reform in the European Union: Review of Progress toward Liberalization \& Integration." The Energy 
Journal, International Association for Energy Economics, vol. 0(Special I), pages 1142.

19. Jouret, Laurent. 2006. "Electricity Market in Poland. Changes on the horizon." ING BANK report.

20. Megginson, W. L., and Netter, J. M., 2001. "From state to market: a survey of empirical studies on privatization," Journal of Economic Literature, Vol. 39, No. 2. (Jun., 2001), pp. 321-389.

21. Nestor, Stilpon and Mahboobi, Ladan. 2000. "Privatization of Public Utilities: The OECD Experience." Privatisation, Competition and Regulation. OECD Centre for Cooperation with Non-Members, Advisory Group on Privatisation. OECD Publications Service. Paris, France.

22. Rassier, D, \& Earnhart, D 2010, 'The Effect of Clean Water Regulation on Profitability: Testing the Porter Hypothesis', Land Economics, 86, 2, pp. 329-344, EconLit, EBSCOhost, viewed 24 June 2011.

23. Ritchie, A., Wilson, K., Grebot, B., Smale, R., Orzeszek, W., Dann, S., Twigger, L., Spencer, I., \& Stravrakaki, A. 2005. "Preparation of the review relating to the Large Combustion Plant Directive: A Report for European Commission, Environment Directorate General. Final Report." Entec UK Limited.

24. Uliasz-Bochenczyk, Alicja and Mokrzycki, Eugeniusz. 2007. "Emissions from the Polish power industry." Energy 32, pp. 2370-2375. 
25. Williams, J.H. and Ghanadan, R. 2006. "Electricity reform in developing and transitional countries: A reappraisal." Energy 31, pp. 815-844. 